\title{
A GRICULTURAL
}

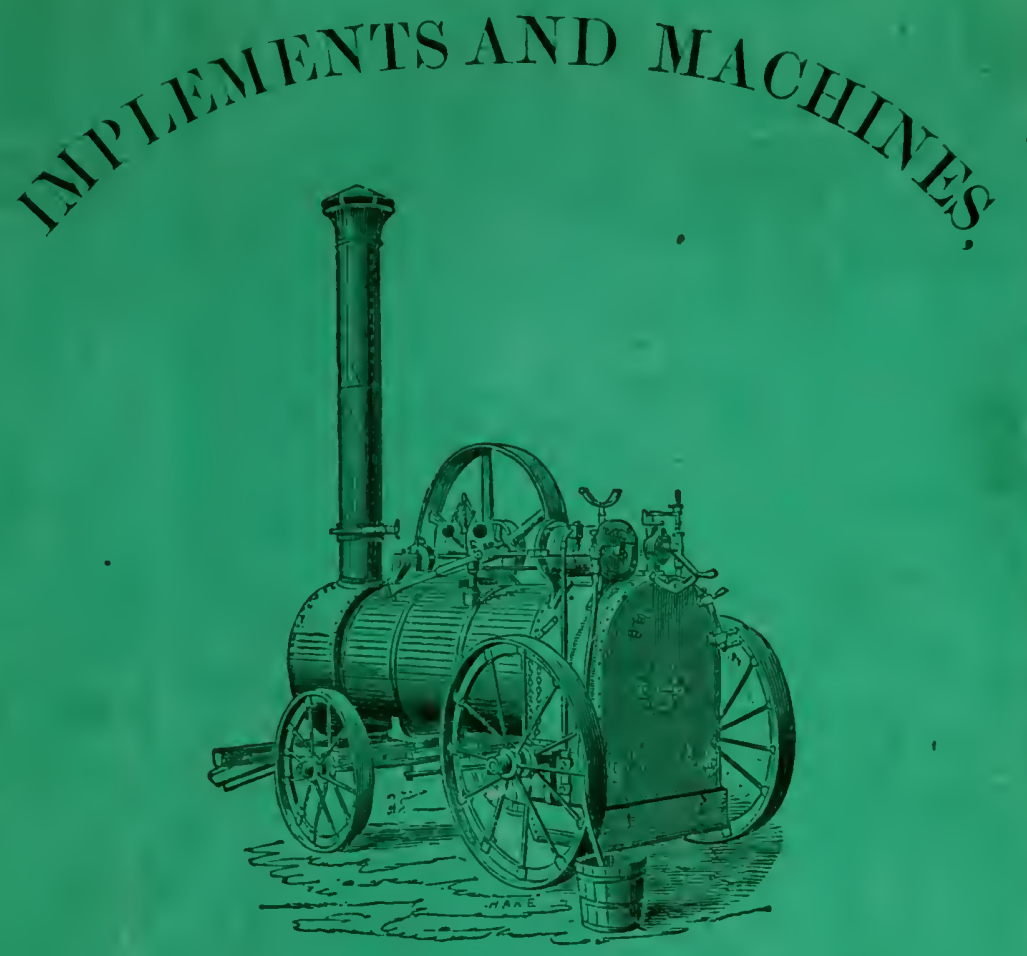

MLNTEACTUREN BY

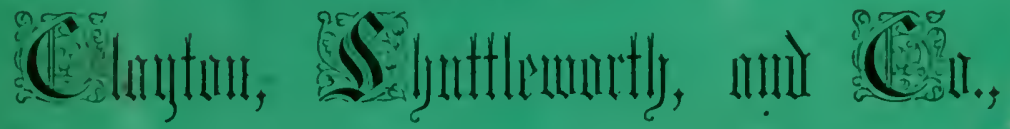
GENERIL, FNGINEERS,

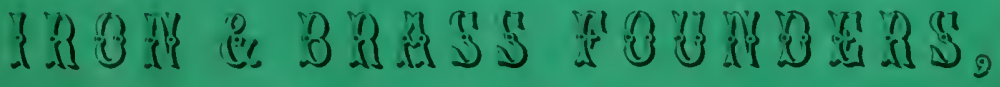
STAMP END IRON WORKS,

\section{LINCOLN.}





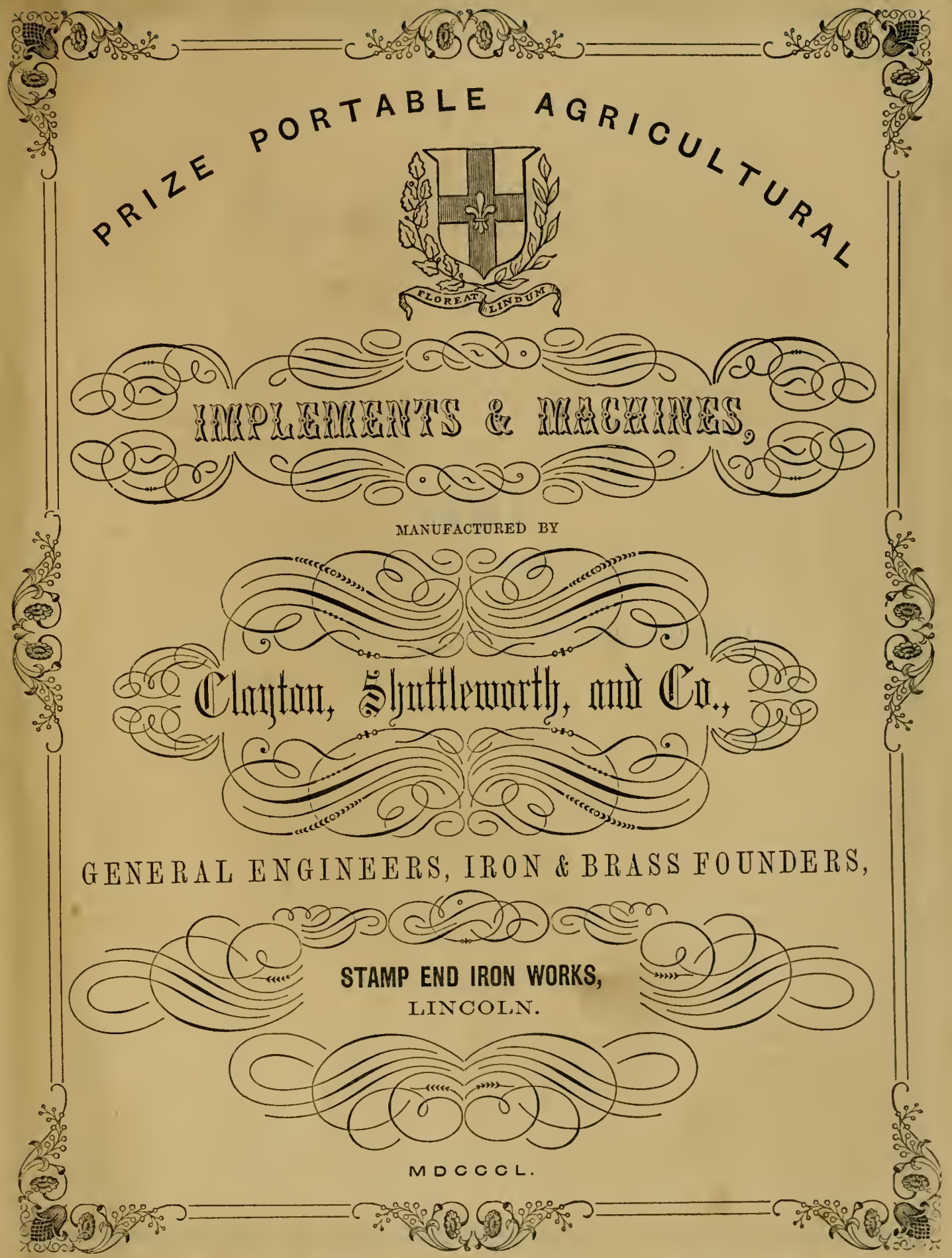




\section{TERMS.}

\section{NETT CASH PAYMENTS.}

Implements delivered at the Lincoli Fiailfay Statrons. 


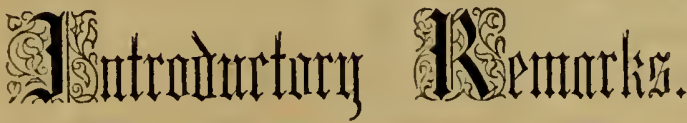

CLAYTON, SHUTTLEIVORTH, \& Co. beg to call the attention of Agriculturists and the Public generally to their fixed and portable Steam Engines, Thrashing Machines, Straw Shakers, Grinding Mills, Bone Mills, Circular Saws, \&c. ; and, in doing this, they deem it necessary to make a few observations in reference to the use of Steam Engines for agricultural purposes, to the manufacture of which C. S. \& Co. have paid special attention, and the circumstance of their having manufactured upon their own premises, and sold the large number of upwards of one hundred and fifty of their Portable Steam Engines since they commenced supplying them-fifty five of which, of various powers, (all for agricultural purposes,) being disposed of in the year 1849. These statements fully prove the demand and indispensable necessity for such engines; in fact, the great economy effected in agricultural operations by the use of steam power, can no longer be considered a theoretical question, but is, we believe, admitted to be a great advantage by all employed or interested in agricultural pursuits, diminishing the necessity for employing so large a number of horses on the farm, thereby effecting an estimated saving of tiventy-five per cent.

That Steam Engines would have been used for farm purposes much earlier than the present time, and to a much greater extent, there can be no doubt, had it not been for the very clumsy and badly constructed engines and boilers which were put into the hands of the agriculturists, the consequence of which was that there was a great deal of money wasted, and after many attempts, and after almost as many disappointments, the application of steam power for the purposes of husbandry was pronounced a failure, which was wrongfully attributed to the want of skill on the part of the farm laborer to manage the same; but the real cause of all this annoyance, loss, and disappointment, arose not so much from the want of ability on the part of the farm laborer, as from want of mechanical knowledge in the makers of those engines and boilers. Steam Engines for farm purposes, were first made, and to some extent at the present time continue to be manufactured by persons who are not steam Engineers, but only farm implement makers, who know nothing of the theory or first principles of a steam engine, consequently can know but little of its manufacture. It may therefore readily be imagined 
what the result would be when defective steam machinery was put in the hands of inexperienced farm laborers.

C. S. \& Co. have for many years been engaged in the manufacture of steam engines, but hare of late directed their attention almost exclusively to a class of engines (portable and fixed) best adapted for agricultural purposes, and at the same time have closely studied the requirements and best method of arranging the in-door implements of a farm when intended to be driven by steam power, and are prepared to give plans and specifications for either large or small occupations, with cost for the whole complete and set to work.

C. S. \& Co. send printed instructions for the easy and complete management of their Steam Engines, a copy of which is given to every purchaser, and by a strict adherence to the directions therein contained, their Engines may be effectually worked by any steady agricultural laborer.

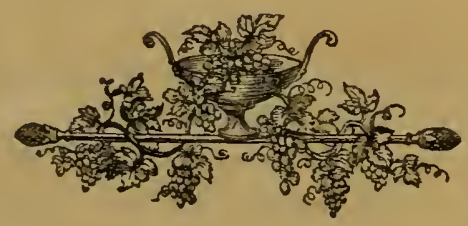




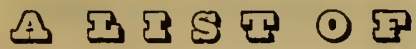 \\ PORTABLE \& FIXED}

S T E A M E N G I N S

AND OTHER AGRICULTURAL IMACHINERY,

MANUFACTURED BY

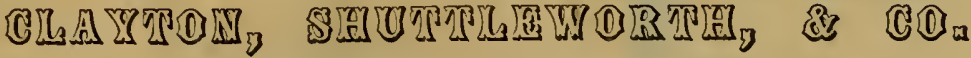
STAMP-END IRON WORKS, LINCOLN.

\section{CLAYTON, SHUTTLEWORTH, \& Co's.} THREE HORSE POWER

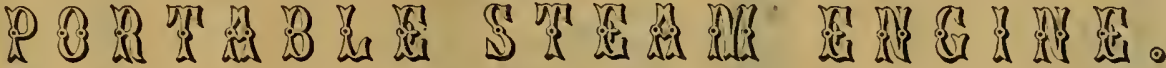

Weight $30 \mathrm{cwt}$.

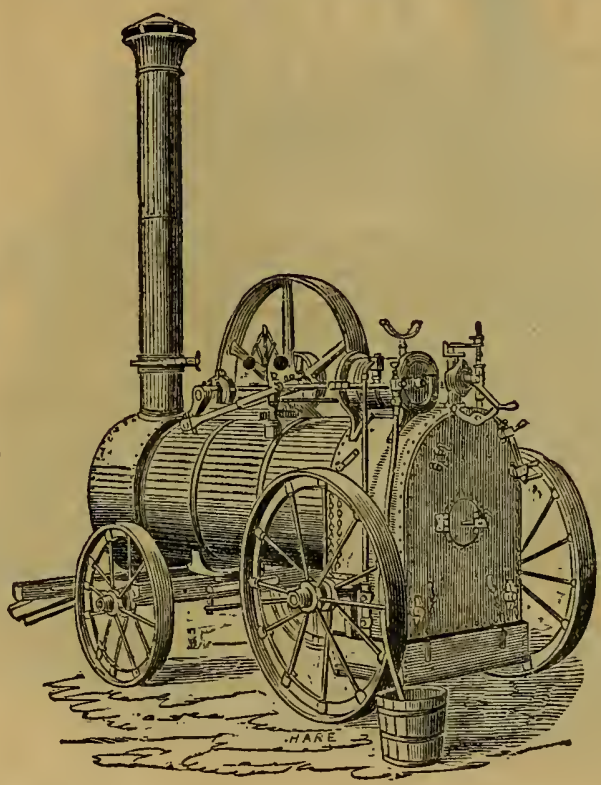

Consumption of Coal per day of ten hours, 3 cwt.

Ditto ditto, of water, 270 gallons.

This Engine is admirably adapted for small occupiers, and will thrash out clean and satisfactorily (crop of a fair average yield) 20 qrs. of wheat per day of ten hours. One horse is sufficient to remove the engine from place to place when on turnpike roads, and, from its extreme lightness, it may be drawn over roads upon a farm when it would be quite impracticable to take an engine of greater weight. 


\section{CLAYTON, SHUTTLEWORTH, \& Co's.}

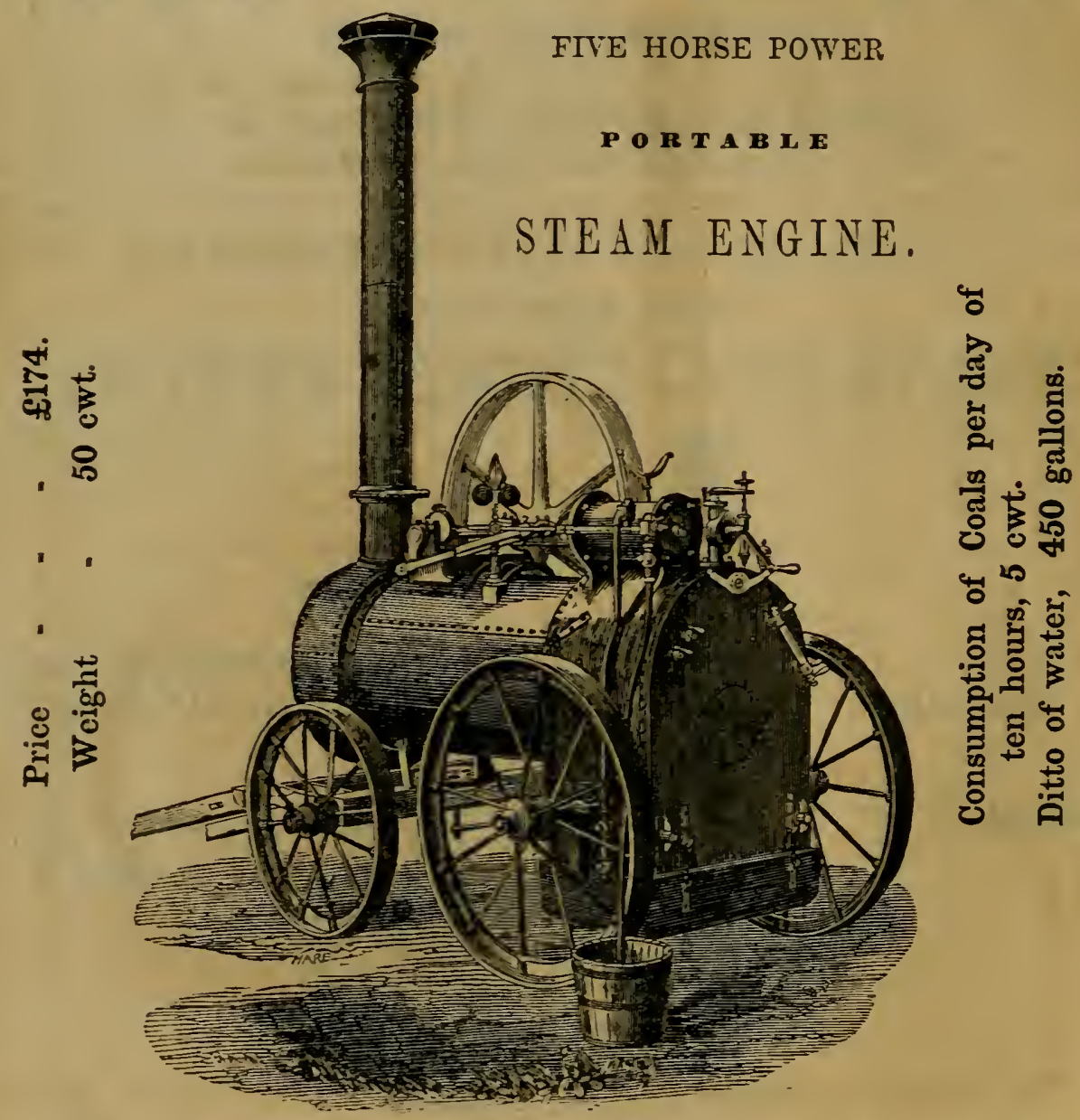

This Engine will thrash out (crop of average yield) 35 qrs. of wheat per day, and in counties where the crops are not very heavy, it is a very suitable engine for men who go from farm to farm, to thrash for hire, being preferred by the famers, (who in all cases hare it either to fetch or take away again,) on account of its lightness, to engines of greater weight. Two horses will walk away with it on a tolerably good road with ease. 


\section{CLAYTON, SHUTTLEWORTH, \& CO'S.}

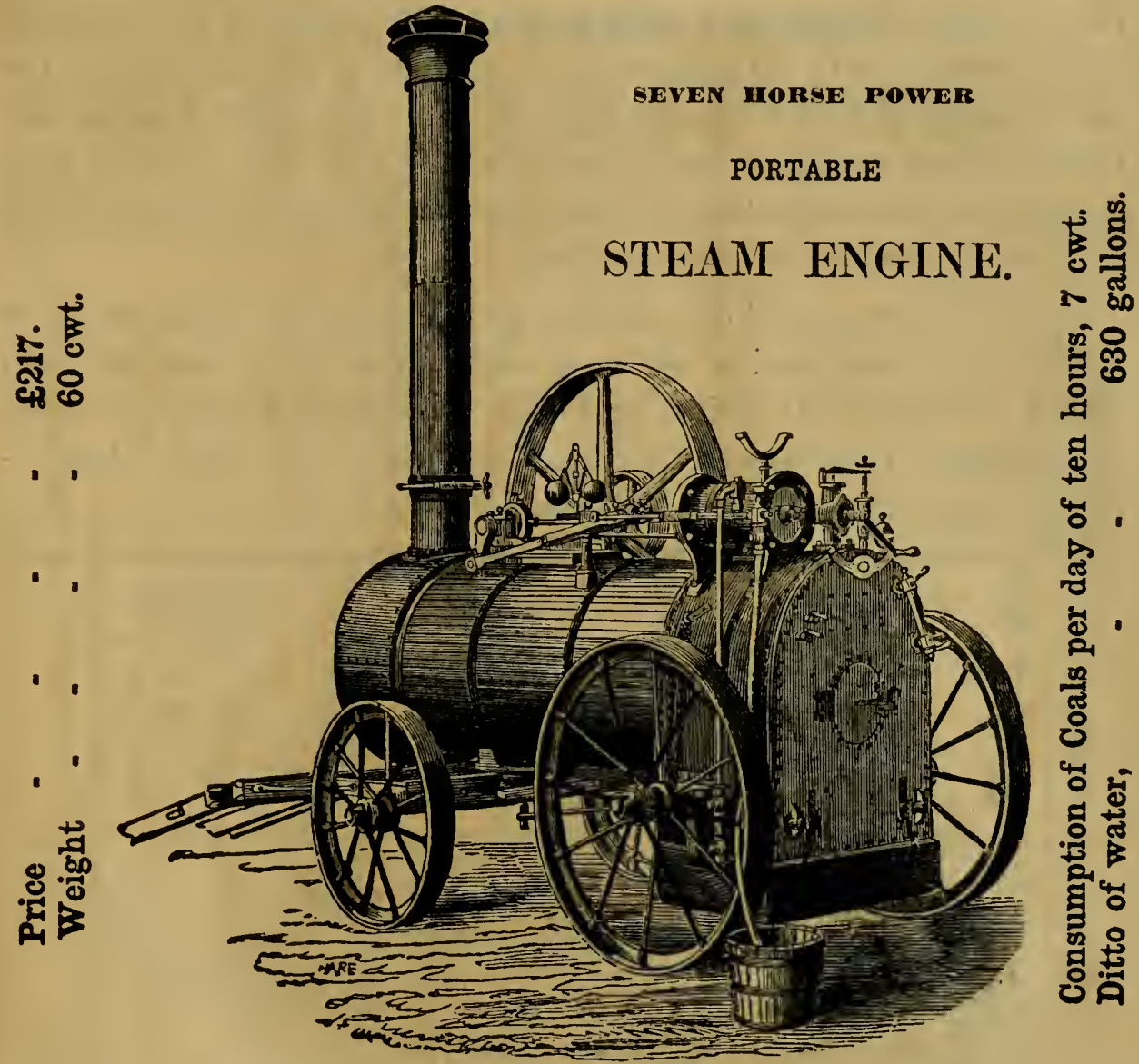

This Engine was exhibited at the Royal Agricultural Show, held at Norwich, in July, 1849, and was awarded a prize of $£ 25$; the same Engine was also awarded the prize of $£ 20$. at the North Lincolnshire Agricultural Show, held at Brigg in the same year. The seven horse power Portable Engine is extremely well adapted for Counties where there is great breadth of corn land, and may be made available for many purposes as well as for thrashing, such as sawing, pumping, or driving the whole of the barn implements upon a farm. We have sold a great 
many of these engines both for private use and for letting out for hire ; they are alike suitable for a small or great day's work, and only consume fuel in proportion to the quantity of work done, therefore they are the most desirable engines for persons who thrash for hire, as they can accommodate either a large or small customer. With a fair average crop, sixty qrs. of mown wheat may be thrashed out in a day of ten hours, with great ease, with one of these engines.

For the information of our readers, and in order to enable them to determine the comparative merits of engines made by various manufacturers, we re-publish the following Tabular Statement of the performance of each engine tested under the Judges' direction, at the Royal Agricultural Society's Show, held at Norwich, 1849.

\begin{tabular}{|c|c|c|c|c|c|c|c|c|}
\hline \multicolumn{7}{|c|}{ TABCLAR STATEJENT OF RESULTS. } & \multicolumn{2}{|c|}{$\begin{array}{l}\text { While working } \\
\text { up to their } \\
\text { Nominal Powers }\end{array}$} \\
\hline Name. & 㝕 & $\stackrel{\dot{j}}{z}$ & 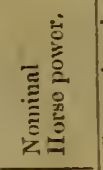 & 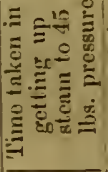 & 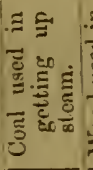 & 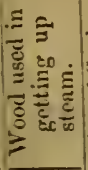 & 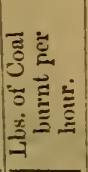 & 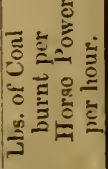 \\
\hline 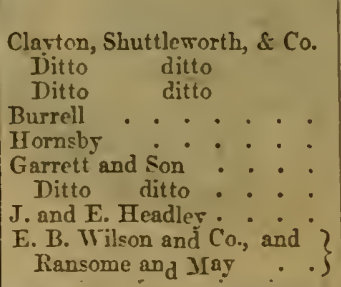 & \begin{tabular}{|r}
5 \\
5 \\
5 \\
13 \\
$6 j$ \\
81 \\
81 \\
83 \\
110 \\
\end{tabular} & $\begin{array}{r}1 \\
2 \\
3 \\
1 \\
8 \\
21 \\
29 \\
21 \\
1 \\
1\end{array}$ & 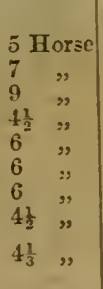 & $\begin{array}{c}\text { Minutes. } \\
44 \\
45 \\
37 \\
57 \\
92 \\
61 \\
63 \\
107 \\
47 \\
0 .\end{array}$ & $\begin{array}{l}\text { lbs. } \\
32 \frac{1}{3} \\
3 \pi \frac{3}{4} \\
41 \frac{1}{1} \\
28 \frac{3}{1} \\
46 \frac{1}{4} \\
59 \frac{3}{4} \\
73 \frac{1}{2} \\
41 \frac{1}{2} \\
29 \frac{1}{4}\end{array}$ & $\begin{array}{l}\text { Ibs. } \\
20 \\
20 \\
20 \\
20 \\
20 \\
20 \\
20 \\
20 \\
20\end{array}$ & $\begin{array}{c}\text { lbs. } \\
59 \\
75 \frac{1}{2} \\
105 \\
114^{\frac{1}{2}} \\
-85^{\frac{1}{4}} \\
84^{\frac{1}{4}} \\
69 \\
108 \\
1\end{array}$ & $\begin{array}{l}\text { lbs. } \\
11.8 \\
10.78 \\
11.66 \\
25.5 \\
14.2 \\
14 \\
11.5 \\
24 \\
14\end{array}$ \\
\hline
\end{tabular}

From the foregoing table the following results may be fairly deduced: 1st. That the engines manufactured by Clayton, Shuttlerrorth, \& Co. get steam up in the least time. 2nd. They require the smallest quantity of fuel in getting up the steam. And 3rd. What is most important, these engines consume less fuel. per horse, per hour, than any which were exlibited at Norwich, thereby showing the great superiority of these engines over every other exhibited there. 


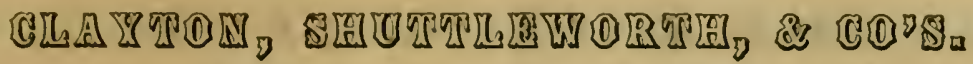
NINE HORSE POWER DOUBLE CYLINDER
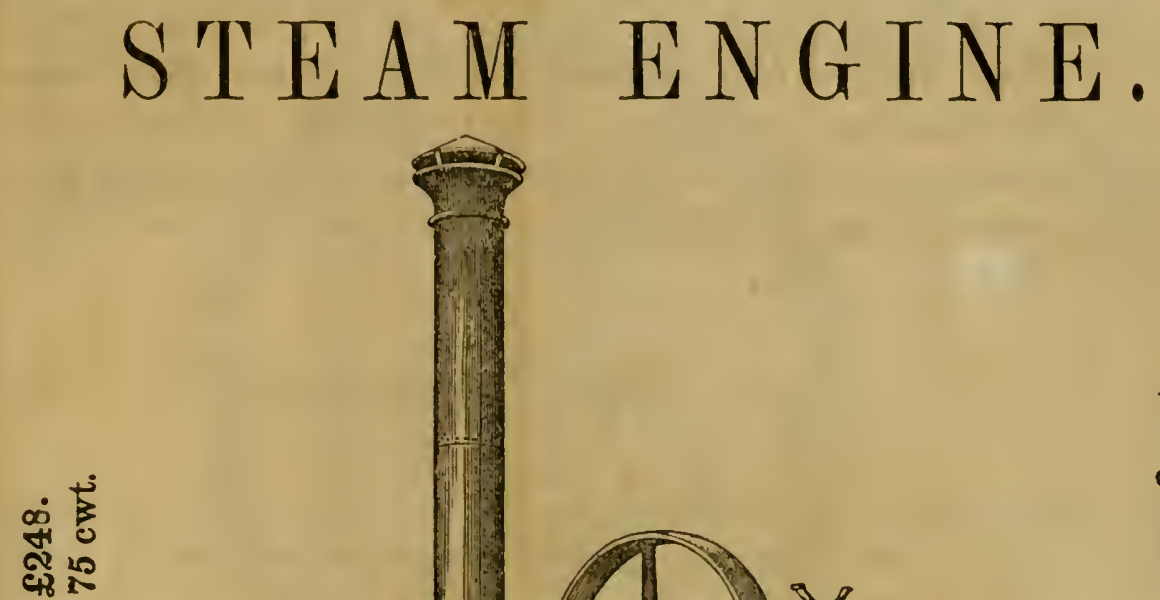

ध

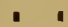

'
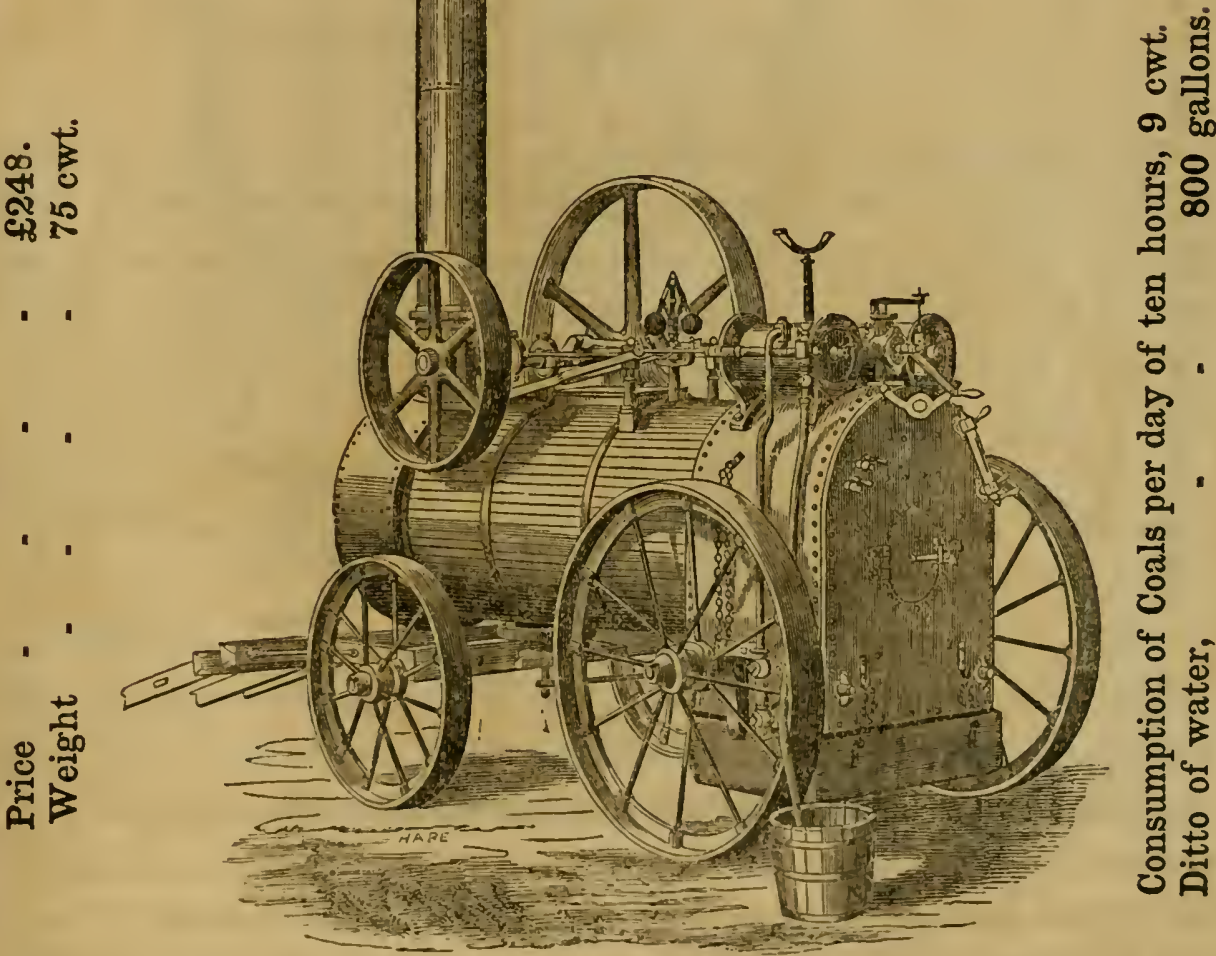

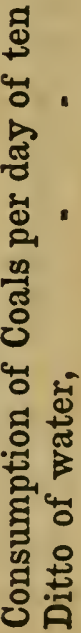

This Engine has more power than agriculturists require in a general way, nevertheless upon large farms where there are mill stones and a quantity of barn implements to drive and much wood to saw, they are found in such cases to answer admirably well, a little surplus power being 
at all times desirable, and when not working at their full limit will only consume fuel in proportion to the work done. We have sold two of these engines for farm purposes in Scotland, and they are very much liked. (See letter from Mr. Dudgeon, of Almond Hill, near Edinburgh, inserted at the end of this catalogue.) There is scarcely any limit to the quantity which may be thrashed with an engine of this power, but in a general way the amount of performance may be stated at $S 0$ or 90 qrs. of mown wheat in ten hours.

The foregoing Engines and Boilers are made of the rery best materials, and by the most skilled workmen that can be got, and are equal in finish to a locomotive. They are fitted with an improved governor which acts with such precision as to have the entire control of the engine, regulating its speed to the greatest nicety under all changes or irregularities of the work. The boiler is covered with hair felt, orer which is placed a neat rood casing, giving a handsome finish to the whole, and prevents radiation of heat, thereby effecting a great saring of fuel, especially in cold weather.

The prices given with each engine include every requisite necessary, not a single item of extras being required. The requisites comprise patent waterproof corer for engine, tube cleaner, fire pricker and rake, screw keys and screw hammer, oil tin, spare guage glass, \&c. 
CUAA

\section{IMPROVED FIXED STEAM ENGINE.}

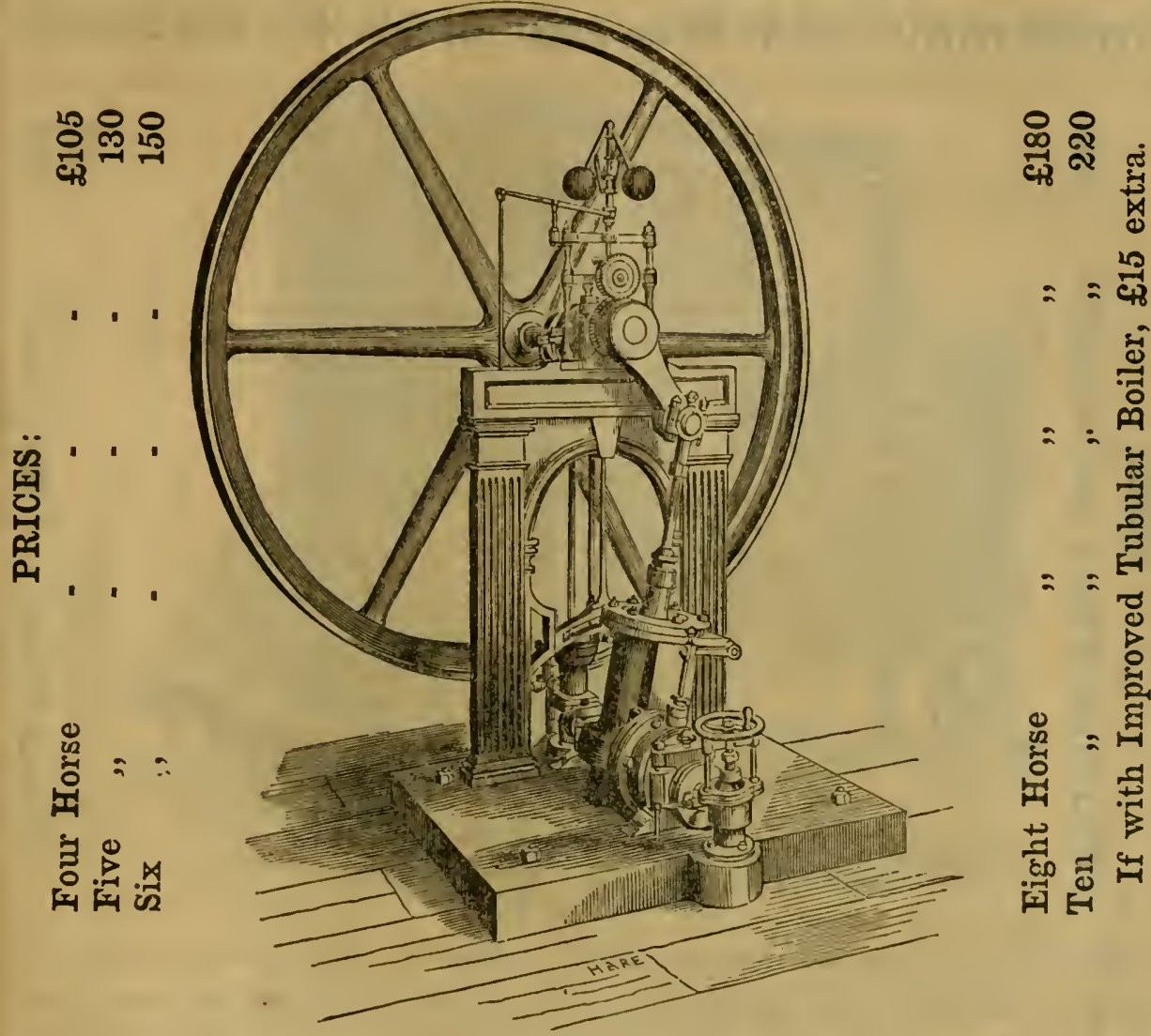

The above Steam Engine is extremely well adapted for Agricultural purposes; having an oscillating cylinder which greatly reduces the number of working parts, thereby rendering it much less liable to get out of repair, better to be understood, and easier to manage than the ordinary table or top beam Engine. The annexed prices include all complete to the end of the fly-wheel shaft and fixing, (exclusive of masonry and brick work), and putting to work, but not carriage beyond Lincoln Railway Station. 


\section{CLAYTON, SHUTTLEWORTH, \& CO'S.}

\section{UNITED}

\section{THRASHING, SHAKING, AND BLOWING MACHINE.}

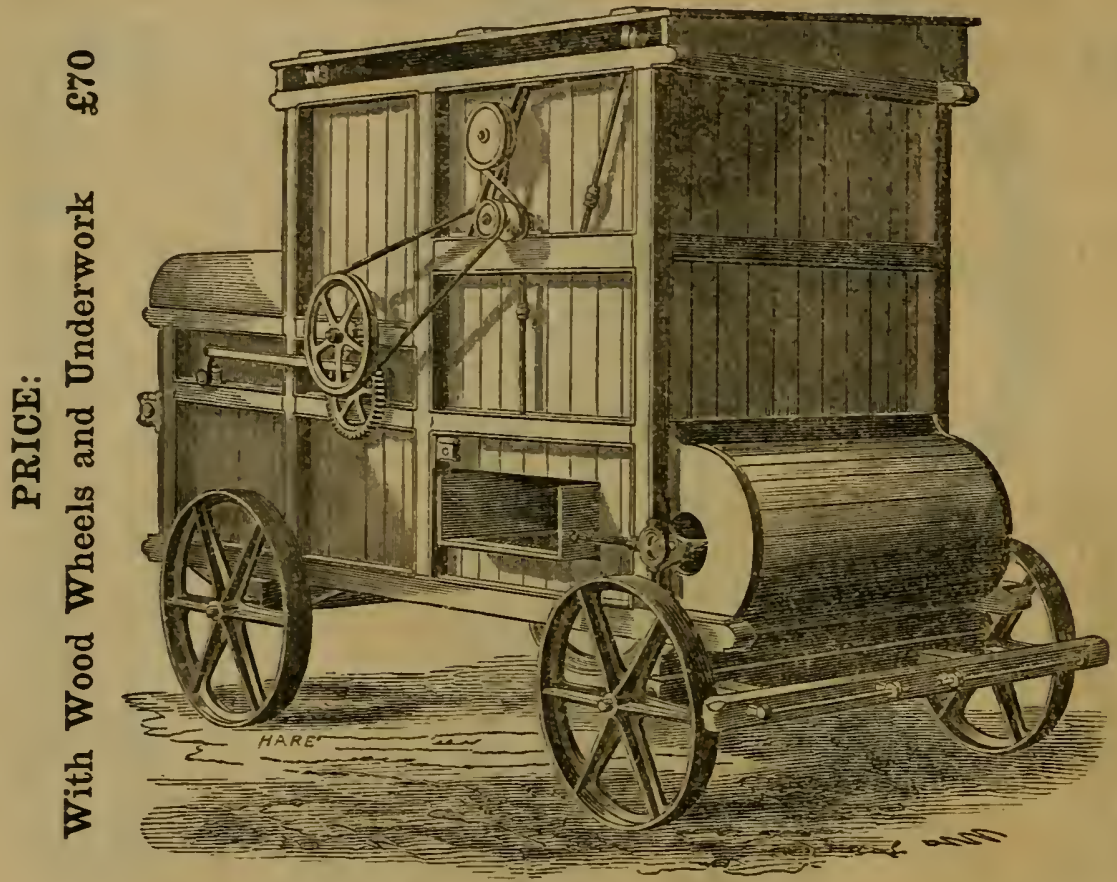

This is an improved machine which Clayton, Shuttleworth, and Co. have recently brought into use, and which will no doubt in a very short time become general; its chief advantages may be enumerated as follows :

In addition to thrashing all kinds of grain, which it does in a very superior style, without injuring the straw ; it combines in itself the advantages of three distinct machines, (and still perfectly portable upon four wheels), viz., a Straw Shaker, for separating the corn from the straw, with revolving cloth underneath, which delivers all which drops through the shaker into a riddle, where also all the loose ears, chaff, and short straws are separated; the chaff and small particles fall through and are 
acted upon by the blower, which separates them from the grain so effectually, that once passing through the ordinary Dressing Machine, finishes it ready for market. The chaff, grain, straw, and loose ears, are all delivered in their separate places, requiring no further labour than taking up and carrying away, thereby considerably diminishing the cost, compared with the old mode of thrashing.

\section{CLAYTON, SHUTTLEWORTH, \& CO'S.}

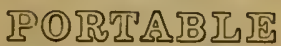

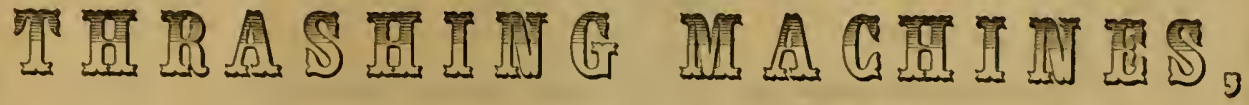

SUITABLE FOR DRIVING WITH STEAM POWER.
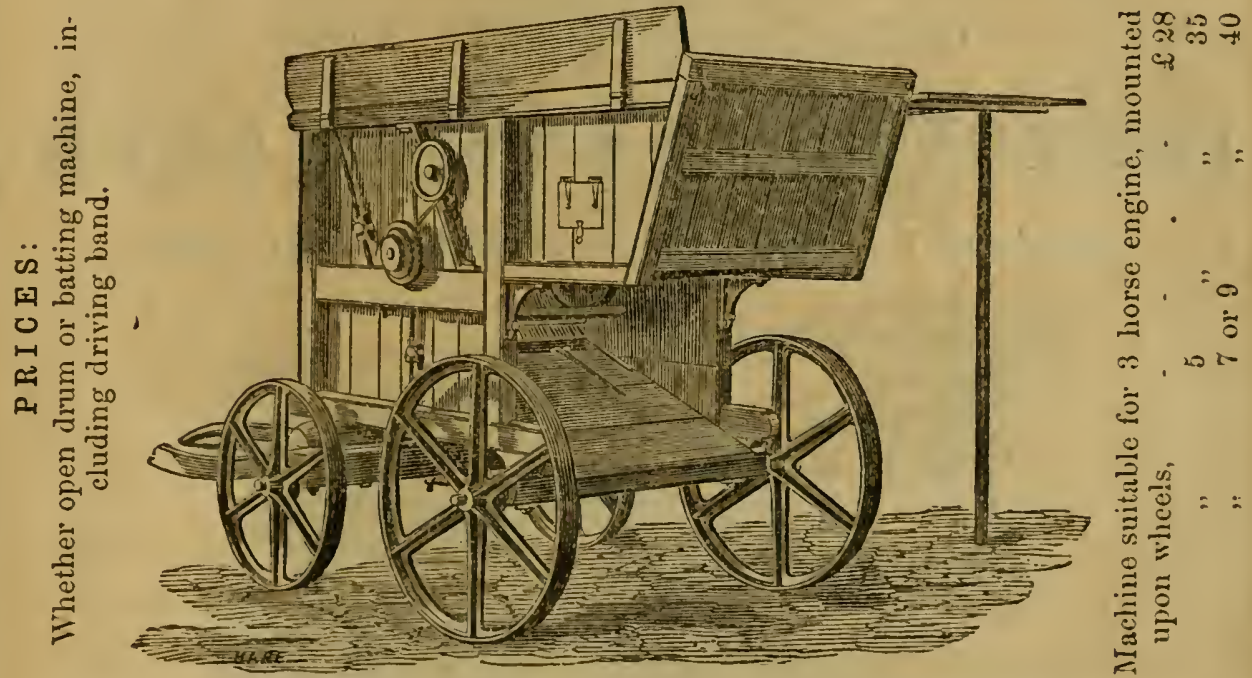

To this branch of the trade C. S. \& Co. have devoted a great deal of time and attention, and having commenced with the determination to use none but timber well-seasoned, and of the best quality, and to employ none but skilled and experienced workmen, they are glad in being enabled to say that they have arrived at such a state of perfection in the manufacture of this class of implements, that for durability and every other quality desirable in a thrashing machine, they stand second to none. 
In situations that will admit of the thrashing machines being fixtures, and elevated upon a second floor, C.S. \& Co. recommend a blowing or chaffing machine, and a straw shaker, with revolving cloth underneath the same, all upon one frame, with elevators to take the corn up into the dressing or finishing machine. But as different situations involve in almost every case an alteration of arrangement, it would be impossible to quote a definite price for such work completed. C. S. \& Co. will in such cases gladly give plans and specifications, with price, for the whole complete, and set to work.

CLAYTON, SHUTTLETORTH, \& CO'S

\section{IMPROVED STRAW SHAKER.}

Fixed upon iron wheels, with shafts complete, for travelling.

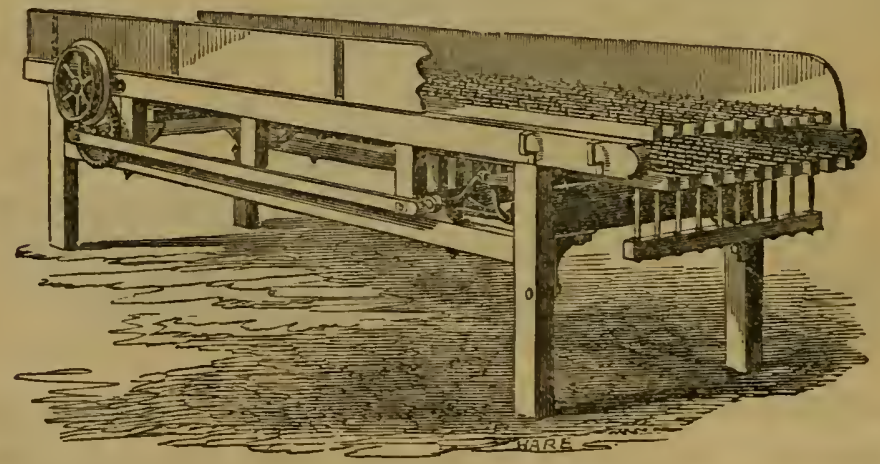

P R I C E S :

15 feet long in the shaking part, and suitable for a 7 or 9 horse engine, \&21

12

9

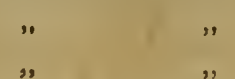

,

5 


\section{CLAY'TON, SHU'T'TLEWORTH, \& CO'S. \\ IREGISTERED TISITE}

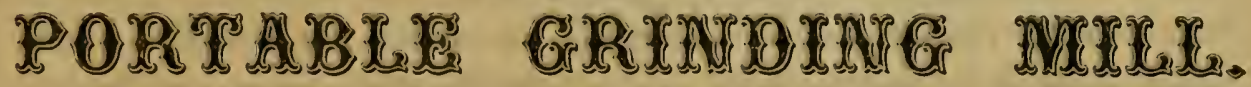
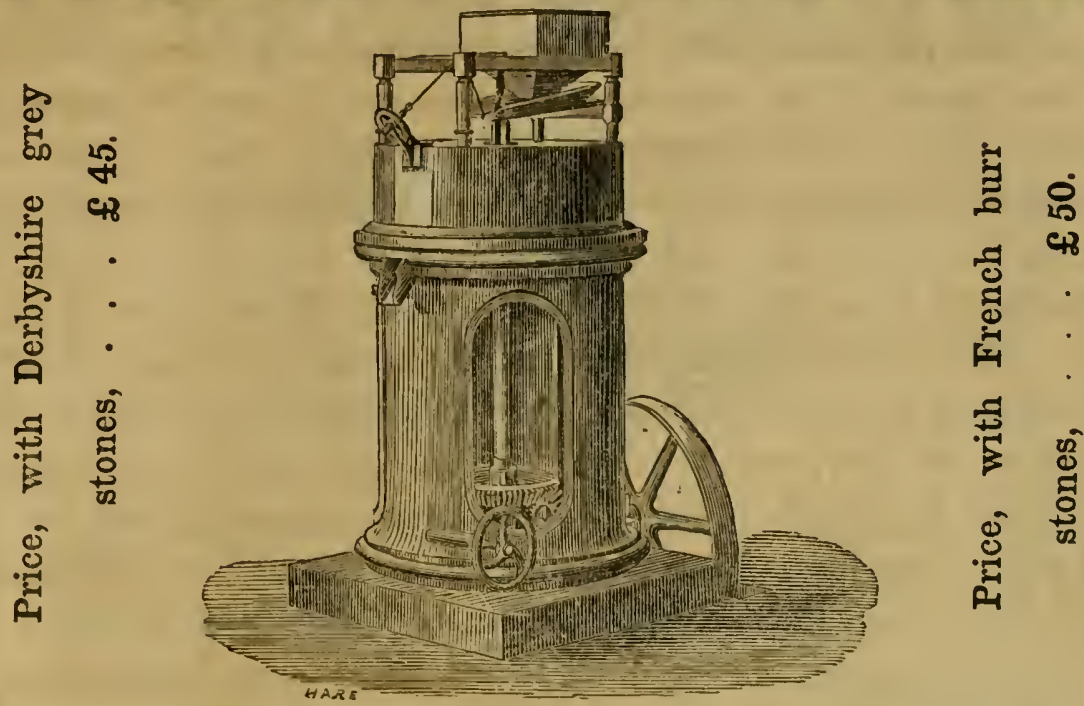

It has long been admitted by all practical agriculturists that by no other method the same amount and quality of work can be done in crushing or kibbling agricultural produce as by a pair of mill stones; knowing this to be the case, and observing no parties had yet brought out any thing at all suitable for such purpose, C. S. \& Co. determined to turn their attention to it, and have got out an article which they can with confidence recommend. With respect to its performance and general adaptation to agricultural purposes, when brought into competition with thirty-two other mills exhibited and tested at the Royal Agricultural Meeting, held at Norwich in 1S49, the Julges in their Report make the following observations:-

"The portable mills for grinding fine meal did not possess much merit, with the ex" ception of Messrs. Clayton and shuttleworth's, to which we awarded the prize. It " both libbled and ground in superior style to any of the others, grinding barley per" fectly well at the rate of 6 bushels per liour without much heating the meal. It was " upon the same principle as fixed mill stones nsually are, as well got up in point of "workmanship, and took little roon, so that we considered it a valuable implement." 
The stones are $2 \mathrm{ft}$. 8 in. diameter, fixed in a metal cylindrical frame $3 \mathrm{ft}, 6 \mathrm{in}$. diameter, and $4 \mathrm{ft}$. $7 \mathrm{in}$. high, from floor to top of bedstone. The top or runner stone is carried round by the upright spindle which receives its motion from the pair of bevelled wheels at bottom, one of which is geared with wood to prevent noise; the pulley shown on the outside is for running the strap, which may be taken direct from the engine driving wheel; the small hand wheel at the bottom in front is for adjusting the stones to their faces, by which means, and in a moment's notice, they may be made to grind to the finest flour, wheat or barley, or be so adjusted as only to bruise or kibble beans, peas, and oats. The quantity of work done in a given time will vary according to the required fineness of the flour; with Derbyshire grey stones six bushels of barley, per hour, may be ground to fine meal, and if only required to be kibbled or partially broken, a much greater quantity may be done. If wheat is intended to be ground, French burr stones are indispensable, and in most cases they are best suited for agricultural purposes, being much harder, consequently do not require dressing or sharpening so often as Derbyshire grey stones.

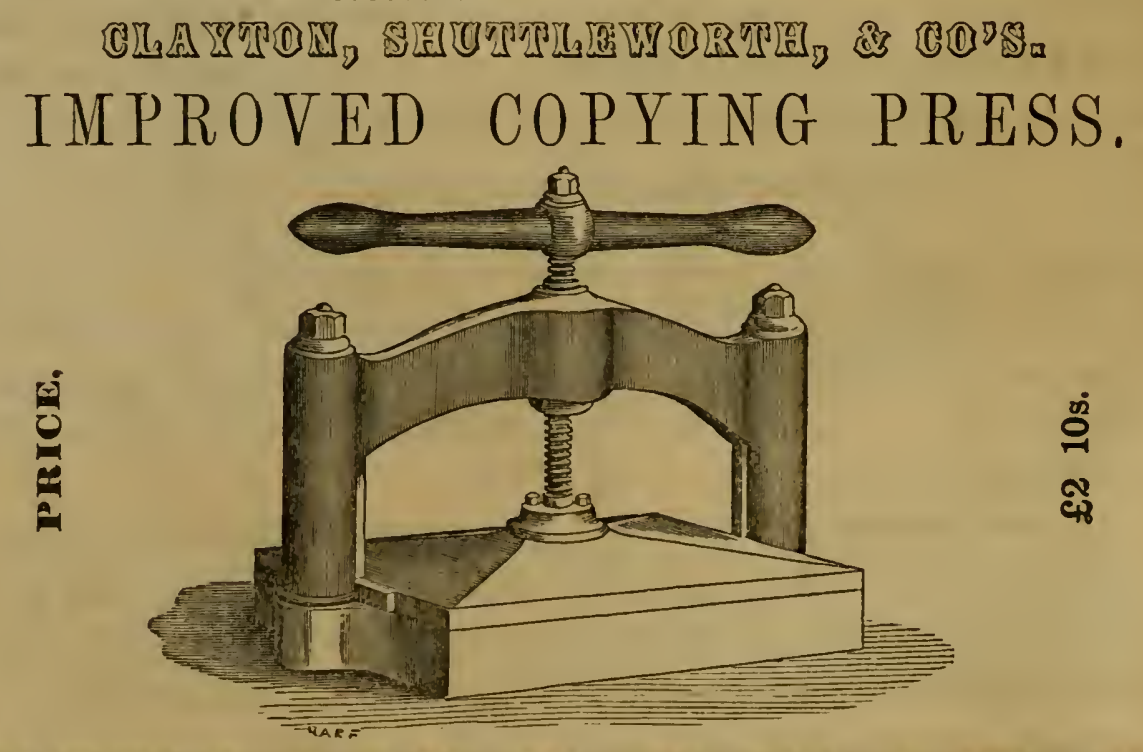




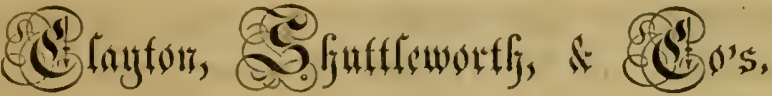 \\ CIIBOULAR}

\section{SAW FRAME FITTED WITH CIRCULAR SAW,}

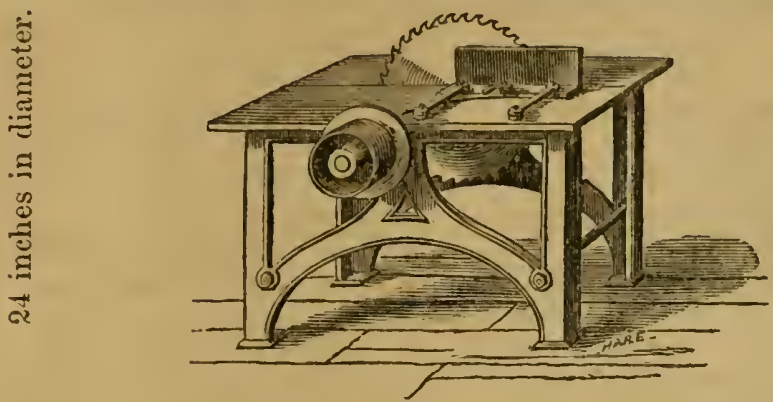

बं

In this frame a circular saw is fixed in planed up iron table complete, and ready for bolting down upon a floor or wood frame, with driving pulley upon end of spindle, and every requisite ready for being set to work at once, without any expenses in the shape of extras. Upon the table is a guard which cannot move in any direction but parallel to the saw; this guard is so arranged that it can, at a moment's notice, be moved nearer to, or farther from the saw, yet always parallel to it, thereby insuring a perfect straight cut the whole length of the timber.

\section{GLAXTON, SHURTLENORTH, \& COS. BONE MILL, Price $£ 80$.}

This Mill, with one pair of cutters, suitable for being driven by steam power, which can be done without any additional machinery, simply by passing a strap over a pulley upon the engine shaft, from thence direct to a pulley upon the bone mill. The bones require to be passed twice through 
the cutters, which have an arrangement for being set closer or farther apart, at pleasure; by this means the bones may crushed to any degree of fineness.

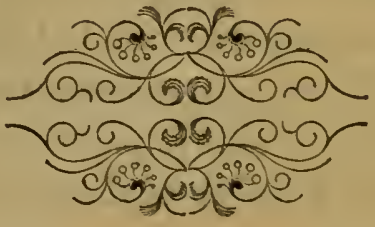




\section{TESTIMONIALS}

To the merits of Messrs. Clayton, Shuttleworth, \& Co's. Engines, Thrashing Machines, \&c., (the originals may be seen on application at the works.)

To the Editor of the Scottish Agrieultural Jourwal.

Almond Hill, near Edinburgir, F'ebruary 9 th, 1849,

Sir,-Observing a paragraph in your excellent paper of the 3rd ult., relating to a Portable Steam Engine made by Messrs. Clayton, Shuttleworth, \& Co., of Lincoln, which was exhibited in Edinburgh on the previous Wednesday, I beg to acknowledge that $I$ was the farmer alluded to in that paragraph who stated, at first sight, that the elegrant little machine before us "wonld do very well to spin thrums," thinking it improbable that so small a bulk could wield so much power as was stated, viz, that of working a thrashing mill usually employing six horses. I now beg to add that I was one of those furmers who went to Dumfriesshire, accompanied by Mr. Patterson, of Meadow-field, and Mr. J. Hume, the intelligent agent of MIessrs. C., S., \& Co., last Friday, for the purpose of examining minutely the capabilities of this compact instrument; and $I$ have much pleasure in stating the result was in cvery degree favourable to the skill of the engineers, so much so, that I fecl convinced their engines will soon be extensively introduced into Scotland. This individual engine was manufactured for Sir Wm. Jarline, Bart.. of Applegarth, for his home firm at Jardine Hall. Requiring no buildings whaterer, we there saw it attached with ease and readiness to the thrashing mill; and it commenced at eleven o'clock in the forenoon to thrash out a good-sized stack of oats, which was finished a considerable time before two in the afternoon-a work which, with six horses in a mill, would, with similar corn, take at least five hours. During the thrashing, repeated attempts were made to overpower the engine by EXCESSIVE FEEDING; but its power was quite superior to all such attempts, and the veRY sMall quantity of fuel used during the operation was quite extraordinary. Sir Wm. Jardine mentioned that he meant to apply it likewise for sawing wood, and making tiles and bricks. A half ton of coals with this engine will thrash as much as a whole ton would do with our ordinary steam engine, and likewise effect a great saving in oil. Its great advantage is, being easily attached to a thrashing machine, and being removed from one place to another by two horses. Another advan. tage would be that, at the end of a lcase, it could either be easily removed or dis. posed of, if the landlord or incoming tenant did not choose to take it at a valuation. I have to remark that, as this is only a five-horse-power engine (mechanical calculation), it might be considered preferable, if it were to be attached to a mill where bruisers and elevators were required, to malie a six horse power. I cannot conclude without noticing the urbanity and kindness of Sir Wm. Jardine, and his lady, to the party: they not only extended to us the utmost hospitality at Jardine Hall, but they also sent a carringe both for us and with us, from and to the railway station.

I am, Sir, fce.

JoIn Dudgeos. 


\section{Canifick, near Lincolas,}

Gentlemen,

19th Junc, 1848.

In answer to your enquiry relative to the "Portable Steam Thrashing Engine" which I purchased of you in June, 1846, I have grcat pleasure in stating that I have found it a very efficientimplement, and one which I would not be without on any consideration. It is very economical, easily moved from place to place, and so simple that one of my own laborers attends to it. It can thrash out more corn per day than twelve horses, does it better, requires no more hands, and only consumes from eight to ten cwt, of coals.

If I can be of any use to you as a reference, I sluall be most happy to answer any enquiry.

- I remain, Gentlemen,

Your obedient servant,

Edwd. Clatike.

To

Messns. Clatton, Shuttleworth, \& Co.

Sunderland Docks, Contractor's Office.

$$
\text { Gextlemex, } \quad 5 \text { th July, } 1848 .
$$

In reply to your enquiry as to how the "Portable Engines" we have had from you suit us, we have to say, they give us entire satisfaction, and far exceed our most sanguine expectations respecting them. Our opinion of them for sawing, Pile Driving, Pumping, \&c. (in fact for the general uses that contractors can apply Engines to), is that, so far as any thing of the sor't that we have seen, they cannot be surpassed, either for doing the same quantity of work with the least quantity of fucl, or for little expense in keeping them in repair.

We are, Gentlemen,

Yours truly,

To

John Craven \& Son.

Messrs. Clatton, Shutri.eirorti, \& Co. Engineers, Stamp-end Works.
Kexwick Hall, Clenchimation, Near Lyx, 18th June, 1848.

Gextlenes,- - It is with great pleasure I send you my opinion of the "Steam Engine and Tlurasher" you made me last year. I hare no hesitation in saying it far surpasses all Ihave seen: its simplicity of construction, compactness, and porta. bility, combined with its accuracy and great power, render it quite a farorite with all who have seen it work.

I approve of the principle of the double cylinder adopted by you, thereby doing away with a ponderous fly-wheel (which, in a Portable Engine adds materially to its weight; consequently is an objection to its being moved about). Thrce horses will move the engine you made me with perfect ease on a tolerable road. The engine is so simple that a farm servant of mine drives it quite as well as any skilled mechanic, and keeps it in good order without any difficulty.

The quantity of coal consumed, all must be aware, will depend upon the quality. I find with good liard coals eight ewt. will work the engine for ten hours; and with that quantity of coals I have thrashed sixty quarters of wheat, the straw of which was very long and stiff, and was loaded on to raggons as thrashed, and there were thirty-four waggon loads. I have no hesitation in saying, that in a season when the straw is not beyond its average length we could thrash a much greater quantity.

I have only to add, you are quite at liberty to make use of this communication in any way you think proper; and any gentlemen you may refer to me, I shall be happy to answer their inquiries.

\section{I am, Gentlemen,}

Yours, \&c.,

Wruliam Staston.

To

Messrs. Clayton, Shuttlewonti, \& Co., Stamp-end Iron Works, Lincoln. 
Manchester, Sheffield, and Lincolnshire

Railway: Locomotive Department. Garto:, Aug. 27, 1849.

\section{Gextrenen,}

I have great pleasure in testifying to the very excellent arringement and quality of workmanship displayed in your Portable Steam Engines: as exhibited at the North Lincolnshire Agricultural Meeting, July, 1849, where they were awarded the first prize.

$$
\begin{aligned}
& \text { I am, Gentlemen, } \\
& \text { Yours most obediently, } \\
& \text { N. PEAcock. }
\end{aligned}
$$

\section{To}

Messrs. Clayton, Shuttueworth, \& Co. Engineers, \&c. Lincoln.

$$
\begin{aligned}
& \text { Framptox Fen, } \\
& \text { July } 26 \text { th, } 1849 .
\end{aligned}
$$

\section{Gentremen,}

Having given your Engine a fair trial, and duly tested its jowers, I thought it incumbent upon me to state my entire satisfaction of the same, and trust, at a future period, to be enabled, (with the ex. perience of my partners also), to signify our approval in every way.

I remain, Gentlemen, Yours respectfully, Geo. Claark.

To

Messrs. Shuttleivorth, \& Co.

$$
\begin{aligned}
& \text { Burcott, Abingdon, } \\
& 27 \text { th August, } 1849 .
\end{aligned}
$$

\section{Dear Sirs,}

The Engine started and has continued to perform its work to the satisfaction of us all. 'The ever true and noiseless way in which it works in every part, is gratifying to see, and a proof of the nature of its workmanship.

In haste,

Yours very truly, Henry Hanvasy.

aLessrs. Clatton \& Co.

\section{Marfitair. Downham, 26 th September, 1849.}

\section{Genteman,}

It is with much pleasure, I assure you, that your engine is all that $I$ could wish, whether as regards its admirable simplicity or the beauty of its censtruction,-its movements are as those of a watch, and it is so simple that any intelligent farm laborer may be taught to work it in a day.

$$
\begin{aligned}
& \text { I am, Gentlemen, } \\
& \text { Yours truly, } \\
& \text { J. Brow.. }
\end{aligned}
$$

Messrs. Clayton, Siuuttleworth, \& Co.

Dear Sir,

$$
\text { Cirateenis, Nov. 1, } 1819 .
$$

Your Engine, certainly, has more than equalled niy expectations, as far as regards its regularity of movement, and the simplicity of management required in working it I think there is no doubt of you soon being required to send into our district two or three similar engines, when certain parties here have seen a little more of the working of this onc, which has excited universal admiration.

$$
\begin{aligned}
& \text { I am, dear Sir, } \\
& \text { Yours truly, } \\
& \text { Johs Lirenen, Jus. }
\end{aligned}
$$

Mr. Shuttleworth.

Gunton Park, Cromer, 4th Jan., 18.18. Gestemenen,

'Ihe Steam Engine and Thrashing Machine received from you have now been fairly tried, and I an glad to be able to express my entire satisfaction with both; the latter I should have been glal to have tried upon a barley stack, but the weather has been so unfiarourable for out-loor operations, that I have not had the opportunity, but have no doubt of its capability to do this work without detriment to the grain.

I remain, Gentlemen, yours truly, Henry Smith. Messrs. Clayton, Shuttleworti \& Co. 


\section{Blofield, Norwich,}

15 th Dec. 1849.

\section{Gentlemen,}

I consider I am in duty bound to inform you that the engine you sent me works admirably well, surpassing my most sanguine anticipation; it has been working almost every day since I have had it, and not the least thing of any importance has got out of order. I consider it su. perior to anything of the sort that has come under my notice; in this opinion erery Agriculturist who has seen it work coincides. Should I ever want another, I shall certainly give you the order. Garrett, of Leiston, has sent two engines to near neighbours of mine; without speaking partially, I have no hesitation in saying they are inferior to yours, which I believe is chiefly owing to the bad construction of their fire-place.

\section{I am, yours truly,}

A. B. Postle.

Messrs. Clatytox \& Co.
Sussex Farm, Lrna,

7 th Feb., 1850.

\section{Gentlemen,}

It gives me much pleasure, now that I have had my engine nearly eight months, and since harvest, constantly at work, that is, three and four days per week, to express my great satisfaction with it,-I reckon that it does for me the work of seren horses, thrashing and dressing corn out of the chaff, and crushing at the same time. My man appears to me thoroughly to understand the working of it, and I have not the slightest trouble in the management. I expect you will hear of some more customers in our neighbourhood.

I am, Gentlemen,

Your most obedient servant, H. E. BLYтн.

Messrs. Shuttleworth \& Co.

Engineers, Lincoln. 


\section{.}

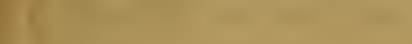
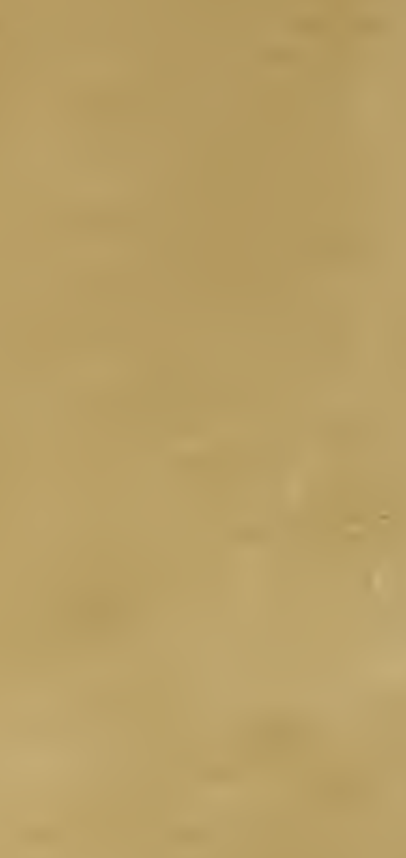

1

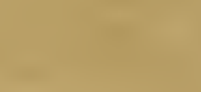




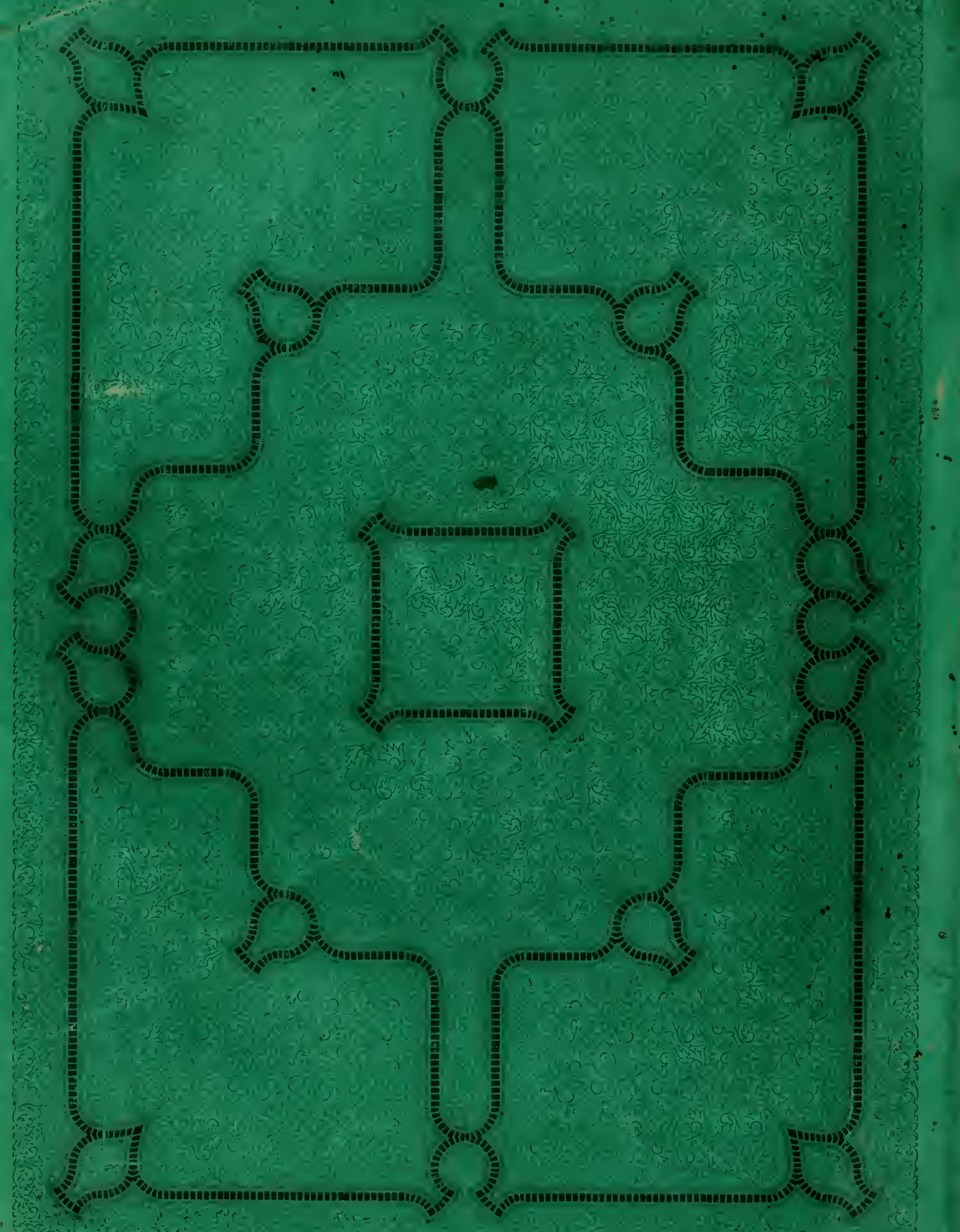

